\title{
Diagnostic Patterns of Iron Deficiency and Iron Deficiency Anaemia in Children of 6 to 59 Months in Cameroon
}

\author{
Sylvie Demanou Agokeng, Anna Longdoh Njunda, Claude Tagny Tayou, Clement Nguedia Jules Assob
}

\begin{abstract}
A Cross sectional multicentre study was carried out to determine the prevalence of Iron deficiency (ID) and Iron deficiency anaemia (IDA) in children using Ferritin and full blood count. Full blood count was done with Mindray Bc-2800 and Ferritin test with Enzyme Linked Immuno-Sorbent Assay. Authorization was granted by Cameroonian national Ethical Committee. Data were analysed using Statistical Package of Social Sciences 21.0 significant results were considered for $\mathbf{P}<$ 0.05. ID varied from $4.2 \%$ to $9.6 \%$ for cut-offs of 30 and $50 \mu \mathrm{g} / \mathrm{L}$. IDA ranged from 4.2 to $8.5 \%$ at these 2 cut-offs. Considering red cells indices, Mean Corpuscular Volume and Mean Corpuscular Haemoglobin blood count currently used should be interpreted cautiously as only Mean Corpuscular Volume and Mean Corpuscular Haemoglobin corroborate with a Ferritin level lower than $30 \mu \mathrm{g} / \mathrm{L}$.
\end{abstract}

Index Terms — anaemia; Ferritin; iron deficiency; Red cells indices.

\section{INTRODUCTION}

Iron is an essential element involved in energy metabolism and other biochemical processes, including oxygen transport in blood, oxidative phosphorylation in cellular respiration, erythropoiesis, and DNA synthesis [1]. While studying the effect of iron supplementation in children, Lozoff et al [2] stated that iron deficiency (ID), a major cause of anaemia can result in intellectual reduction and motor function damage. It has also been revealed about micronutrients deficiency in developing countries, that every second, about $40 \%$ of preschool children are estimated to be anaemic [3]. In Cameroon for instance, demographic and health surveys, reported that $60 \%$ of children aged from 6 to 59 months were anaemic [4].

Iron deficiency anaemia (IDA) is a world health problem and a burden to half of the world's population, its prevalence varies widely by geography, age and sex [5]. WHO estimates that IDA resulted in 273000 deaths: out of which $45 \%$ in southeast Asia, 31\% in Africa, 9\% in the eastern Mediterranean, $7 \%$ in the Americas, $4 \%$ in the western pacific and $3 \%$ in Europe. This means $97 \%$ of deaths occurs in low and middle income countries [6]. Economically the loss due to IDA in 10 developing countries was estimated at $4 \%$ of gross domestic income [7].

In many developing countries, iron deficiency anaemia is aggravated by worm infections, malaria and other infectious diseases such as HIV and tuberculosis. Cameroon national survey found that the prevalence of ID in children of 12-59

Published on August 31, 2020.

S. D. Agokeng, Bertoua Regional Hospital, University of Buea, Cameroon. (corresponding e-mail: agdesy ${ }^{\circledR}$ yahoo.fr)

A. L. Njunda, University of Buea, Cameroon.

(e-mail: ann_njunda@yahoo.com) months of age ranged from $14 \%$ to $68 \%$ depending on the indicator and adjustment for inflammation applied [8].

The aim of this study was to determine the prevalence of ID and IDA in children through Ferritin test recommended by WHO and evaluate the effectiveness of full blood count, the commonest test available in Cameroonian health settings.

\section{MATERIALS AND MethodS}

\section{A. Materials}

Data were collected through a questionnaire, after parental agreement. Once the identification of the children was done, blood was drawn into EDTA tube for full blood count and dry tube for Ferritin analysis.

\section{B. Methods}

This was a cross sectional multicentre study carried out at the Bertoua regional Hospital, Douala Gynaeco-Obstetric and Paediatric Hospital and Yaounde University Hospital Centre from November 2018 to October 2019. The target population was children of 6 to 59 months attending the different study sites. Sample size was calculated using the Lorentz formula. All the children of the target age visiting the paediatric unit and having a prescription of full blood count were included. Children with Haemoglobin $(\mathrm{Hb})$ level $<11 \mathrm{~g} / \mathrm{dL}$ were considered anaemic and those with $\mathrm{Hb} \geq 11 \mathrm{~g} / \mathrm{dL}$ were nonanaemic [9]. Children with neurologic affection or motor dysfunction were not included in the study. Full blood count testing was performed using Mindray Bc-2800. Anaemic children were classified into severe $(\mathrm{Hb}<7 \mathrm{~g} / \mathrm{dL})$, moderate (Hb: 7-9.99 g/dL) and mild (Hb: 10-10.99 g/dL). Three Erythrocytes parameters were considered: Mean Corpuscular Volume (MCV < 80fl), Mean Corpuscular Haemoglobin $(\mathrm{MCH}<26 \mathrm{pg})$ and Mean Corpuscular Haemoglobin Concentration $(\mathrm{MCHC}<32 \mathrm{~g} / \mathrm{dL})$. Blood in dry tubes were centrifuged at $2500 \mathrm{G}$ for 5 minutes to obtain serum. The serum was kept at $-20^{\circ} \mathrm{C}$ for batch analysis of Ferritin using ERBALISA Kits by Cal Biotech Lab (USA) at the serology bench of the main laboratory of the Bertoua Regional Hospital. Normal values for this kits were given for men and women but not for children. We considered different cut-offs, of 30 and $50 \mu \mathrm{g} / \mathrm{L}$ to estimate the prevalence of ID and IDA. This study was approved by the Cameroon National Ethical Committee for Research in human health, the Regional delegations of public health of the East and Centre regions, the scientific committee of the Douala Gynaeco-Obstetric and Paediatric Hospital.

C. T. Tayou, University of Yaounde, University Hospital Centre, Cameroon (e-mail: tayouclaude ${ }^{@}$ yahoo.fr).

C. N. J. Assob, University of Douala, Cameroon (julesclement@yahoo.fr). 
The collected data were computed in Excel 2013 and analysed with Statistical Package for Social Sciences SPSS (version 21.0) for Windows (SPSS Inc., Chicago, IBM, USA) using Pearson's Chi Square and Fisher exact tests, a 95\% confidence interval $(95 \% \mathrm{CI})$ with $\mathrm{P}$ value $<0.05$ for significant difference. Receiver Operating Characteristics (ROC) curves analysis was used to test the performance of Ferritin cut-offs of 30 and $50 \mu \mathrm{g} / \mathrm{L}$.

\section{RESULTS}

383 children were recruited during this study from the three regions, 243 at the Bertoua Regional Hospital, 95 from Douala Gynaeco-Obstetric and Paediatric Hospital and 45 from Yaounde University Hospital Centre. Male were more represented than female with $56.1 \%$. The children were mostly of the age of 6 to 23 months with a mean of $25.2 \pm 0.7$ months (Table I).

TABLE I: Distribution OF CHILDREN (6 - 59 MONTHS) ACCORDING TO

\begin{tabular}{ccc}
\multicolumn{3}{c}{ SOCIO-DEMOGRAPHIC DATA } \\
\hline $\begin{array}{c}\text { Socio-demographic data } \\
\mathrm{N}=383\end{array}$ & Category & $\begin{array}{c}\text { Number per } \\
\text { category }(\%)\end{array}$ \\
\hline Gender & Male & $215(56.1)$ \\
Age (months) & Female & $168(43.9)$ \\
& & \\
& $6-23$ & $184(48)$ \\
Caregivers' education level & $24-41$ & $124(32.4)$ \\
& $42-59$ & $75(19.6)$ \\
& & \\
& None & $27(7.1)$ \\
& Primary & $18(4.7)$ \\
& Secondary & $236(61.6)$ \\
& University & $102(26.6)$ \\
& & \\
Child's education & None & $256(66.8)$ \\
& Pre-nursery & $32(8.4)$ \\
& Nursery & $89(23.2)$ \\
& Primary & $6(1.6)$ \\
\hline
\end{tabular}

\section{A. ID tested by Ferritin}

With 2 different cut-offs level experienced for Ferritin, iron deficiency was observed in $4.2 \%$ of children for Ferritin cut-off $<30 \mu \mathrm{g} / \mathrm{L}$ and $9.6 \%$ for Ferritin cut- off $<50 \mu \mathrm{g} / \mathrm{L}$ (Fig. 1).

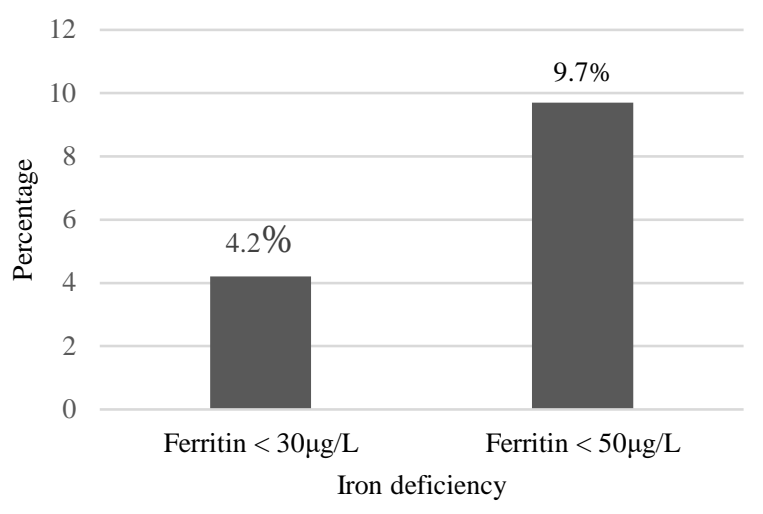

Fig. 1. Iron deficiency in children considering a Ferritin cut-offs $<30 \mu \mathrm{g} / \mathrm{L}$ and $<50 \mu \mathrm{g} / \mathrm{L}(\mathrm{N}=383)$.

\section{B. IDA tested by Haemoglobin level and Ferritin}

In total among the recruited 383 children, $44.4 \%$ (170) were non anaemic. Ferritin level did not relate to the gravity of anaemia, thus all the children with severe anaemia had a Ferritin level $>100 \mu \mathrm{g} / \mathrm{L}$ (Table II). Additionally, all the children with Ferritin lower than $30 \mu \mathrm{g} / \mathrm{L}$ suffered of mild or moderate anaemia.

TABLE II: DisTRIBUtion OF ANAEMIC CHILDREN REGARDING THE TyPE AND THE SEVERITY OF ANAEMIA

\begin{tabular}{|c|c|c|c|c|c|c|}
\hline Variable & Category & Severe & Moderate & Mild & Total & $\begin{array}{c}\text { Fisher } \\
\text { exact }\end{array}$ \\
\hline $\mathrm{N}=213$ & & $\mathrm{n}(\%)$ & $\mathrm{n}(\%)$ & $\mathrm{n}(\%)$ & $\mathrm{n}(\%)$ & (p-value) \\
\hline \multirow[t]{5}{*}{$\begin{array}{c}\text { Anaemia's } \\
\text { type }\end{array}$} & & & & & & $\begin{array}{c}8.794 \\
(0.161)\end{array}$ \\
\hline & IDA & $0(0)$ & $4(1.9)$ & $5(2.3)$ & $9(4.2)$ & \\
\hline & IDA/ACD & $0(0)$ & $26(12.2)$ & $\begin{array}{c}21 \\
(9.9)\end{array}$ & $\begin{array}{c}47 \\
(22.1)\end{array}$ & \\
\hline & $\mathrm{ACD}$ & $\begin{array}{c}19 \\
(8.9)\end{array}$ & $69(32.4)$ & $\begin{array}{c}68 \\
(31.9)\end{array}$ & $\begin{array}{c}157 \\
(73.7)\end{array}$ & \\
\hline & Total & $\begin{array}{c}19 \\
(8.9)\end{array}$ & 99 (46.5) & $\begin{array}{c}95 \\
(44.6)\end{array}$ & $\begin{array}{c}213 \\
(100)\end{array}$ & \\
\hline
\end{tabular}

The mean Ferritin level was $290.6 \pm 12.8 \mu \mathrm{g} / \mathrm{L}$ for all the children, with a mean of $242.2 \pm 16.2 \mu \mathrm{g} / \mathrm{L}$ in non anaemic lower than the mean in anaemic children $(329.2 \pm 18.6 \mu \mathrm{g} / \mathrm{L})$. The frequency of IDA varied from $4.2 \%$ to $8.5 \%$ with respective cut-offs of 30 and $50 \mu \mathrm{g} / \mathrm{L}$ (Fig. 2).

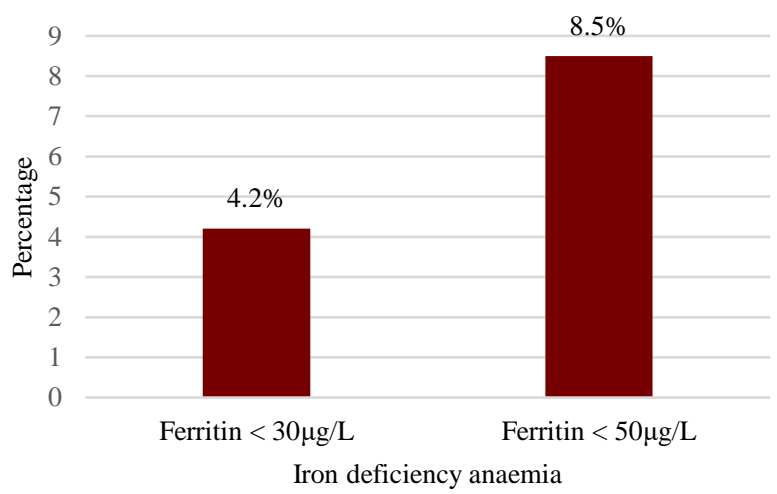

Fig. 2. Iron deficiency anaemia in children considering a Ferritin cut-offs $<$ $30 \mu \mathrm{g} / \mathrm{L}$ and $<50 \mu \mathrm{g} / \mathrm{L}(\mathrm{N}=213)$. 
The ROC curves testing the performance of Ferritin cutoffs at 30 and $50 \mu \mathrm{g} / \mathrm{L}$ showed that the area under curve (AUC) of $30 \mu \mathrm{g} / \mathrm{L}(0.985)$ was greater than the one of 30 and $50 \mu \mathrm{g} / \mathrm{L}$ (0.936) (Fig.3).

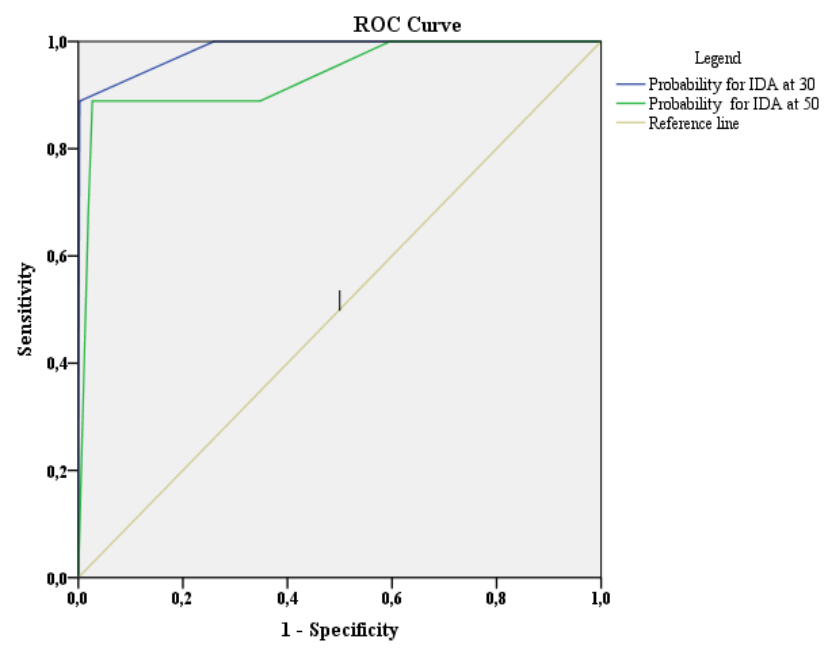

Fig. 3. Receiver Operating Characteristics (ROC) curves for 2 cut-offs of Ferritin in IDA.

\section{Red cells indices and ID}

Using full blood count to determine iron deficiency showed consistent results while considering low MCV, low $\mathrm{MCH}$ and a Ferritin cut off $<30 \mu \mathrm{g} / \mathrm{L}(4.2 \%)$. Oppositely low $\mathrm{MCHC}$ revealed iron deficiency only in one quarter $(1 \%)$ of the children tested by Ferritin.

Looking into anaemia and red cells indices, we found that MCHC showed a significant difference between anaemic and non anaemic children with a $\mathrm{P}=0.002$ (Table III).

TABle III: AsSociation Between ANAEMIA AND Red CEll INCICES

\begin{tabular}{|c|c|c|c|c|}
\hline \multirow[t]{2}{*}{$\begin{array}{l}\text { Variable } \\
\mathrm{N}=383\end{array}$} & \multirow[t]{2}{*}{ Category } & $\begin{array}{c}\text { Anaemia } \\
(213)\end{array}$ & $\begin{array}{c}\text { No } \\
\text { anaemia } \\
(170)\end{array}$ & \multirow[t]{2}{*}{$\begin{array}{c}\text { Chi square } \\
\text { (p-value) }\end{array}$} \\
\hline & & $\mathrm{n}(\%)$ & $\mathrm{n}(\%)$ & \\
\hline \multirow[t]{2}{*}{$\mathrm{MCV}$} & Microcytic & $173(45.1)$ & $145(37.9)$ & \multirow[t]{2}{*}{$2.671(0.263)$} \\
\hline & $\begin{array}{l}\text { Normal to } \\
\text { Macrocytic }\end{array}$ & $40(10.5)$ & $25(6.5)$ & \\
\hline \multicolumn{5}{|c|}{ OR (CI) $0.711(0.409-1.235)$} \\
\hline \multirow[t]{2}{*}{$\mathrm{MCH}$} & Hypochromic & $164(42.8)$ & $121(31.6)$ & \multirow[t]{2}{*}{$1.681(0.195)$} \\
\hline & Normal & $49(12.8)$ & $49(12.8)$ & \\
\hline \multicolumn{5}{|c|}{ OR (CI) $1.355(0.855-2.148)$} \\
\hline \multirow[t]{2}{*}{$\mathrm{MCHC}$} & & & & \multirow[t]{2}{*}{$9.824(0.002)$} \\
\hline & $\begin{array}{l}\text { Hypochromic } \\
\quad \text { Normal } \\
49(1.325-3.485\end{array}$ & $\begin{array}{r}69(18.0) \\
144(37.6)\end{array}$ & $\begin{array}{c}31(8.1) \\
139(36.1)\end{array}$ & \\
\hline
\end{tabular}

There was no significant difference between microcytic and macrocytic status regarding Ferritin level with a $P$ value of 0.564 . This was the same for hypochromic or normal status found by $\mathrm{MCH}$ and $\mathrm{MCHC}$ levels with $\mathrm{P}$ value of 0.169 and 0.598 respectively (Table IV).

Looking at IDA (Table V), our results showed that the best red cells index was MCV followed by $\mathrm{MCH}$ with no significant difference found $(\mathrm{P}=0.349$ and $\mathrm{P}=0.314$ respectively).
TABLE IV: Association BetweEn Red CELLs Indices AND FERRITIN

\begin{tabular}{|c|c|c|c|c|c|}
\hline \multicolumn{6}{|c|}{ LEVEL } \\
\hline $\begin{array}{l}\text { Variable } \\
\mathrm{N}=383\end{array}$ & Category & $\begin{array}{c}\text { Low (16) } \\
<30 \mu \mathrm{g} / \mathrm{L} \\
\mathrm{n}(\%)\end{array}$ & $\begin{array}{c}\text { Normal (98) } \\
30-100 \mu \mathrm{g} / \mathrm{L} \\
\mathrm{n}(\%)\end{array}$ & $\begin{array}{c}\text { High }(279) \\
>100 \mu \mathrm{g} / \mathrm{L} \\
\mathrm{n}(\%)\end{array}$ & $\begin{array}{c}\text { Fisher } \\
\text { Exact } \\
\text { (p-value) }\end{array}$ \\
\hline \multirow[t]{3}{*}{$\mathrm{MCV}$} & & & & & $\begin{array}{c}3.924 \\
(0.133)\end{array}$ \\
\hline & Microcytic & $16(4.2)$ & 75 (19.6) & $227(59.3)$ & \\
\hline & $\begin{array}{l}\text { Normal to } \\
\text { Macrocytic }\end{array}$ & $0(0)$ & $13(3.3)$ & $52(13.6)$ & \\
\hline \multirow[t]{3}{*}{$\mathrm{MCH}$} & & & & & $\begin{array}{c}3.195 \\
(0.221)\end{array}$ \\
\hline & Hypochromic & $14(3.7)$ & $70(18.3)$ & $201(52.5)$ & \\
\hline & Normal & $2(0.5)$ & $18(4.7)$ & $78(20.4)$ & \\
\hline \multirow[t]{3}{*}{$\mathrm{MCHC}$} & & & & & $\begin{array}{c}0.611 \\
(0.737)\end{array}$ \\
\hline & Hypochromic & $5(1.3)$ & $25(6.8)$ & $70(18.3)$ & \\
\hline & Normal & $11(3.9)$ & $63(16.4)$ & 209 (54.6) & \\
\hline
\end{tabular}

TABLE V: RED CELLS INDICES AND IRON DEFICIENCY ANAEMIA

\begin{tabular}{|c|c|c|c|c|}
\hline $\begin{array}{l}\text { Variable } \\
\mathrm{N}=213\end{array}$ & Category & $\begin{array}{c}\text { Ferritin (9) } \\
<30 \mu \mathrm{g} / \mathrm{L} \\
\mathrm{Hb}<11 \mathrm{~g} / \mathrm{dL}\end{array}$ & $\begin{array}{c}\text { Ferritin (204) } \\
\geq 30 \mu \mathrm{g} / \mathrm{L} \\
\mathrm{Hb}<11 \mathrm{~g} / \mathrm{dL}\end{array}$ & $\begin{array}{c}\text { Fisher } \\
\text { Exact } \\
\text { (p- value) }\end{array}$ \\
\hline $\mathrm{N}=213$ & & $\mathrm{n}(\%)$ & $\mathrm{n}(\%)$ & \\
\hline \multirow[t]{3}{*}{$\mathrm{MCV}$} & & & & $0.878(0.349)$ \\
\hline & Microcytic & $9(4.2)$ & $164(77)$ & \\
\hline & $\begin{array}{l}\text { Normal to } \\
\text { Macrocytic }\end{array}$ & $0(0)$ & $40(18.8)$ & \\
\hline \multirow[t]{3}{*}{$\mathrm{MCH}$} & & & & $1.012(0.314)$ \\
\hline & Hypochromic & $8(3.8)$ & $156(73.2)$ & \\
\hline & Normal & $1(0.4)$ & $48(22.6)$ & \\
\hline \multirow[t]{3}{*}{$\mathrm{MCHC}$} & & & & $1.602(0.206)$ \\
\hline & Hypochromic & $4(1.9)$ & $65(30.5)$ & \\
\hline & Normal & $5(2.3)$ & $139(55.3)$ & \\
\hline
\end{tabular}

\section{DISCUSSION}

Male sex and the younger age mostly represented in our study, were consistent with the study of Moschovis et al while studying risk factors among young children in sub-Saharan Africa [10], this may be explained by the accelerated growth velocity during the first year of life, since growth velocity is higher in boys when compared to girls during this period [11].

\section{A. ID tested by Ferritin}

While using cut-off level of 30 and $50 \mu \mathrm{g} / \mathrm{L}$ experienced for Ferritin level, iron deficiency that varied from $4.2 \%$ to 9.6\% questioned the real level of Ferritin to be used in children to assess iron shortage. This has been previously raised by Turgeon and collaborators in Canadian children who was proposed to raise the level to $50 \mu \mathrm{g} / \mathrm{L}$ [12] and Phiri's team proposing a value of $273 \mu \mathrm{g} / \mathrm{L}$ in area with high pressure of infection and inflammation [13].

\section{B. IDA tested by Haemoglobin level and Ferritin}

In this study Ferritin did not relate to the gravity of anaemia, as observed, children with severe anaemia instead had high level of Ferritin. This may highlight the fact that anaemia of chronic disease had an impact on Ferritin known as an acute phase protein $[14,15]$. Iron deficiency often considered the primary cause of (severe) anaemia, as a result, the terms anaemia, iron deficiency and iron deficiency anaemia were often interchanged. This is incorrect as 
anaemia can occur with sufficient iron stores and iron deficiency in the initial phase does not necessarily lead to anaemia [16]. The prevalence of ID and IDA in our study population were lower as compared to previous study in Cameroon [8] and elsewhere [17].

The mean Ferritin level was $290.6 \pm 250 \mu \mathrm{g} / \mathrm{L}$ for all the children, the mean in non anaemic $(242.2 \pm 211.9 \mu \mathrm{g} / \mathrm{L})$ was lower than the mean in anaemic children $(329.2 \pm 241$ $\mu \mathrm{g} / \mathrm{L})$. This was different from what was obtained by Kisangani et al who concluded that anaemia predisposed to iron deficiency [18]. This difference may be due to variation in infection rates according to the area of study or related to the national implementation of iron supplementation in pregnant women as done in Cameroon. The aim of this supplementation is to have in normal circumstances iron replete mothers that will deliver iron replete children [19].

In all the children suffering of IDA, none had a request for Ferritin test, showing that physician is not following WHO recommendations on the algorithm of IDA. The reason may be the cost and availability of the test. It was observed that in 2 of the 3 health settings where the research was done, Ferritin test was available but not forcefully prescribed for the diagnosis of IDA. This can be managed if there are means to sensitize prescribers to ask for Ferritin test in case of suspicious IDA so that when used frequently, the cost will also be reduced.

\section{Red cells indices, ID and IDA}

Using full blood count to determine iron deficiency showed that low MCV and low MCH were good predictors of ID compared to low MCHC. These results are in accordance with Turkish study revealing that $\mathrm{MCV}$ and $\mathrm{MCH}$ are parallel parameters [20] but not consistent with those of Koren et al. who observed that MCV and MCHC were a good predictor of iron deficiency in African refugees in Syria [21]. This suggest that Microcytic and hypochromic erythrocytes are more reflected by these 2 parameters in addition to the increase of red cell distribution width (RDW) more and more recommended by researchers in the diagnosis of ID and IDA [22], [23]. We did not consider RDW in our study due to units variation used by the different sites.

\section{CONCLUSION}

Ferritin recommended by WHO for ID and IDA diagnosis was not used in our health settings. Full blood count currently used should be interpreted cautiously as only MCV and MCH corroborate with a Ferritin level lower than $30 \mu \mathrm{g} / \mathrm{L}$ not MCHC.

The use of Ferritin for the diagnosis of iron deficiency and iron deficiency anaemia should be promoted in health settings where it is available and oriented for other purposes. Alternatively, full blood count should be considered for monitoring iron deficiency anaemia when Ferritin cannot be included in the diagnostic process but inflammation impact should be integrated.

\section{ACKNOWLEDGMENTS}

To all the parents and guardians who kindly accepted the participation of their children in this study. To the laboratory and paediatric personnel of the Bertoua Regional Hospital,
Douala Gynaeco-Obstetrics and Paediatric Hospital, Yaounde University Hospital Centre.

\section{REFERENCES}

[1] Calarge CA, Ziegler EE. Iron deficiency in pediatric patients in longterm risperidone treatment. $J$ Child Adolesc Psychopharmacol. 2013;23(2):101-9.

[2] Lozoff B, Jimenez E, Hagen J, Mollen E, Wolf AW. After treatment for iron deficiency in infancy. Pediatrics. 2000;105(4):E51.

[3] WHO. The global prevalence of anaemia in 2011. Geneva: World Health Organisation. 2015.

[4] Modestine M, Sop K, Mananga M. Original Research Article Risk factors of anemia among young children in rural Cameroon. Int J Curr Microbiol Appl Sci. 2015;4(2):925-35.

[5] Kassebaum NJ, Jasrasaria R, Naghavi M, Wulf SK, Johns N, Lozano $\mathrm{R}$, et al. Plenary Paper red cells, iron, and erythropoiesis. A systematic analysis of global anemia burden from 1990 to 2010. Blood J. 2015;123(5):615-25.

[6] Pasricha S, Drakesmith H, Black J, Hipgrave D, Biggs B. Review Article Control of iron deficiency anemia in low- and middle-income countries.Blood . 2013;121(14):2607-17.

[7] WHO. Nutritional Anaemias :Tools for Effective Prevention [Internet]. World Health Organization.

2017.83p.https://www.who.int/nutrition/publications/micronutrients/ anaemias-tools-prevention-control/en/.

[8] Engle-Stone R, Nankap M, Ndjebayi AO, Erhardt JG, Brown KH. Plasma Ferritin and Soluble Transferrin Receptor Concentrations and Body Iron Stores Identify Similar Risk Factors for Iron Deficiency but Result in Different Estimates of the National Prevalence of Iron Deficiency and Iron-Deficiency Anemia among Women a. $J$ Nutr. 2013;143(3):369-77.

[9] WHO. Serum ferritin concentrations for the assessment of iron status and iron deficiency in populations. Vitamin and Mineral Nutrition Information System. Geneva, World Health Organization, 2011 (WHO/NMH/NHD/MNM/11.1).

[10] Peter P Moschovis, Matthew O Wiens, Lauren Arlington, Olga Antsygina, Douglas Hayden,Walter Dzik et al. Individual, maternal and household risk factors for anaemia among young children in sub-Saharan Africa: a cross sectional study. BMJ Open 2018;8:e019654. doi:10.1136/bmjopen-2017-019654.

[11] Gisele A Bortolini, Márcia R Vitolo. Relationship between iron deficiency and anemia in children younger than 4 years. J Pediatr (Rio J). 2010;86(6):488-492.

[12] Turgeon O'Brien H, Blanchet R, Gagné D, Lauzière J, Vézina C. Using soluble transferrin receptor and taking inflammation into account when defining serum ferritin cutoffs improved the diagnosis of iron deficiency in a group of Canadian preschool inuit children from nunavik. Anemia. 2016. Article ID 6430214, 10 pages http://dx.doi.org/10.1155/2016/6430214.

[13] Phiri KS, Calis JCJ, Siyasiya A, Bates I, Brabin B, Boele Van Hensbroek M. New cut-off values for ferritin and soluble transferrin receptor for the assessment of iron deficiency in children in a high infection pressure area. J Clin Pathol. 2009;62(12):1103-6.

[14] Timo Takala. Soluble transferrin receptor role in detection of iron deficiency. 2017. $25 \mathrm{p}$.

[15] Garcia-Casal MN, Pasricha SR, Martinez RX, Lopez-Perez L, PeñaRosas JP. Serum or plasma ferritin concentration as an index of iron deficiency and overload. Vol. 2015, Cochrane Database of Systematic Reviews. 2015.

[16] Femkje AM Jonker, Elodie T Poel, I Bates and Michael B van Hensbroek. Anaemia, iron deficiency and susceptibility to infection in children in sub-Saharan Africa, guideline dilemmas. Br J Haematol. 2017; 177:878-883.

[17] Lama A Youssef, Issam N Albaroudi, Majed Khodder. Prevalence of Iron Deficiency and Iron Deficiency Anemia in Syrian Infants. Blood. 2014; $\quad 124 \quad$ (21): $\quad 5975$. doi: https://doi.org/10.1182/blood.V124.21.5975.5975.

[18] I Kisiangani, C Mbakaya, A Makokha, D Magu. Assessment of iron status among preschool children (6 to 59 months) with and without malaria in Western Province, Kenya.PamJ. 2015; 21:62. doi:10.11604/pamj.2015.21.62.4560

[19] Parkin PC, Maguire JL. Iron deficiency in early childhood. Cmaj. 2013;185(14):1237-8.

[20] Özdemir N. Iron defciency anemia in children. Türk Ped Arş 2015; 50: $11-9$

[21] Gideon Koren, Lielle Ross, Oren Zwang and Orel Benari. Israel JHealth Pol Res (2019) 8:81 https://doi.org/10.1186/s13584-0190351-3. 
[22] Sazawal S, Dhingra U, Dhingra P, Dutta A, Shabir H, Menon VP BR Efficiency of red cell distribution width in identification of children aged 1-3 years with iron deficiency anemia against traditional hematological markers. BMCPediatr. 2014; 14:8. doi: 10.1186/14712431-14-8.

[23] Eun Y Joo, Keun Y Kim, Dong H Kim, Ji-Eun Lee, And Soon Ki Kim.. Iron Deficiency Anemia In Infants And Toddlers. Blood Res. 2016; 51(4): 268-273.

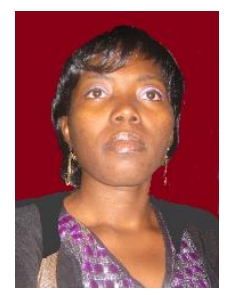

Agokeng Demanou Sylvie was born on the 19th July 1983 at Douala Cameroon. $\mathrm{PhD}$ candidate in Chemical Pathology, Faculty of Health Sciences , University of Buea, Master degree in Biomedical sciences with Major in Medical Immunology, Faculty of Medicine and biomedical sciences, University of Yaounde 1 in 2008; Bachelor's degree in biochemistry, Faculty of sciences, University of Dschang in 2005.

She is the laboratory Quality manager and Head of the Cytology unit for cervical cancer screening at the Bertoua Regional Hospital. Former positions: Regional leader for the promotion of blood donation; Blood Bank leader; Laboratory manager. Publications: Agokeng D. Sylvie, Tayou T. Claude, Assob N. Clement, NJunda anna L.Factors Affecting ferritin level in children of 6 to 59 Months in the Eastern region of Cameroon. International journal of blood research and review, 2019. Agokeng D. Sylvie, Mogou R. Amandine, Ottop F. Manyi, Assob N. Clement. Comparative study between SD BIOLINE Malaria Ag pf rapid diagnostic test and calibrated thick smear in the east region of Cameroon. International Journal of Scientific Research and Management. 2019. Research interests are focus on transfusion and noncommunicable diseases like Malaria, microfilaria, Cancer.

Ms. Agokeng is an active Medical laboratory scientist, member of Higher Institute for Growth in health research and African Organization for Research and Training in Cancer.

Njunda Anna Longdoh was born on the $8^{\text {th }}$ March 1963 at Bamenda, Cameroon. PhD in Medical Microbiology and Parasitology, University of Lagos,Nigeria in 1997. Associate in Medical technology in 1995, Master degree in Medical Microbiology and Parasitology in 1989, Bachelor's degree in Microbiology in 1988.

She is the Vice Dean in charge of students and studies affairs at the Faculty of Health Sciences, University of Buea. Former positions: Vice Dean in charge of Programming and academic affairs, Head of department, Research officer, European Union Filariasis vaccine Project.

Publications:

1. Njunda AL, Assob NJC, Nsagha DS, Atetsam TIL and Kwenti TE. The Distribution of ABO and Rhesus Antigens and the Presence of Irregular Antibodies to Rhesus Antigens in Individuals Resident in the Centre Region of Cameroon. Research and Reviews: Journal of Medical and Health Sciences.RRJMHS. 2014,3(1).

2. Njunda AL, Assob NJC, Nsagha DS,Ndefon P,kamga HLF, Ajebe FN, Kwenti TE. Uropathogens from diabetic patients with asymptomatic bacteriuria and urinary tract infections. The West London Medical Journal. 2013, 5 (1) 7-14.

Dr. Njunda is member of Nigeria Society for Parasitology, Cameroon Bioscience Society, Third World Organization for Women in Science, National Association for Women in Academics, American Society for Microbiology.

Tayou Tagny Claude Bertrand was born on the $12^{\text {th }}$ April 1972 at Foumban Cameroon.Master degree in Transfusion medicine 2008, MS in Clinical Biology, Faculty of Medicine and Biomedical Sciences. University of Yaoundé I (Cameroon) in 2006.Medical Doctor in 1998.

$\mathrm{He}$ is Associate Professor of Haematology at the Department of Haematology of the Faculty of Medicine and Biomedical Sciences, Yaoundé Cameroon.

Dr Tayou is member of Cameroonian Society of Laboratory Medicine (SCBC), African Society for Blood Transfusion (AfSBT), French Society for Blood Transfusion (SFTS), French Society of Haematology (SFH), International Society of Blood Transfusion (ISBT),World Federation of Hemophilia

Assob Nguedia Jules Clement was born on the $6^{\text {th }}$ Febuary 1974 at Bafang Cameroon. PhD in Biochemistry (with Honourable Distinction)University of Yaoundé I, Faculty of Sciences, Cameroon in 2005; D.E.A. in Biochemistry, Major in Advanced Microbiology, University of Yaoundé I, Faculty of Sciences, Cameroon in 2001; Master's degree in biochemistry with Major in Medical Laboratory Sciences (With Honours). University of Dschang, Faculty of Sciences, Cameroon in 2000; Bachelor's degree in biochemistry (with Honours) University of Dschang, Faculty of Sciences, Cameroon in 1997.

$\mathrm{He}$ is the Vice Dean In Charge of Research And Cooperation at the Faculty of Medicine and Pharmaceutical Sciences, Douala Cameroon. Former Positions: Coordinator Post-Graduate Studies, Head of Department Medical Laboratory Sciences, Acting Head of Department Biomedical Sciences, Coordinator, Medicine Programme; Faculty of Health Sciences, University of Buea.

Publications:

1. Efundem Nelsy T. Efundem, Jules Clement N. Assob, Vitalis F. Feteh and Simeon-Pierre Choukem. Prevalence and associations of microalbuminuria in proteinuria-negative patients with type 2 diabetes in two regional hospitals in Cameroon: a cross-sectional study. BMC Res Notes (2017) 10:477, DOI 10.1186/s13104-017-2804-5.

2. Tabouguia Octavie Merveille, Zofou Denis, Njouendou Jelil Abdel, Anneh Abegewi Ursula, Aurelien Fleury A. Moumbock Adie, Babiaka Borakoraeye Smith, Nganyewo Allen Zipoh, Yong Ngwain Joseph, Nde Fon Peter, Penlap Beng Veronique, Assob Nguedia Jules Clement. Antimicrobial Activities of Some Medicinal Plants Against Multiresistants Microorganisms Causing Urogenital Tract Infections in Cameroon. Journal of Diseases and Medicinal Plants. Vol. 3, No. 2, 2017, 33-41. doi: 10.11648/j.jdmp.20170302.12.

3. Jude E. Enoh, Benjamin D. Thumamo Pokam, AniekanAugusta O.Eyo, Ifeyinwa M. Okafor, Jules Clement Assob Nguedia, Boris T Fominyam, and Marcelin Ngowe Ngowe. Drug induced hematological disorders in patients on antituberculosis drugs in the south west region of Cameroon. European Journal Of Pharmaceutical And Medical Research. 2017,4(1),155-161.

Prof. Assob is Associate Editor of The African Journal of Integrated Health (AJIH), an official Journal of the Faculty of Health Sciences, University of Buea, Cameroon. 